\title{
Cross-species Amplification of Microsatellite Loci Developed for Passiflora edulis Sims. in Related Passiflora Species
}

\author{
Gilmara Alvarenga Fachardo Oliveira ${ }^{1}$, Juliano Gomes Pádua ${ }^{2}$, Juliana Leles Costa ${ }^{1}$, \\ Onildo Nunes de Jesus ${ }^{3}$, Fabiana Moraes de Carvalho ${ }^{4}$ and Eder Jorge de Oliveira ${ }^{3 *}$ \\ ${ }^{I}$ Universidade Federal do Recôncavo da Bahia; Campus de Cruz das Almas, Cruz das Almas - BA - Brasil. \\ ${ }^{2}$ Embrapa Recursos Genéticos e Biotecnologia; Parque Estação Biológica; Brasília - DF - Brasil. ${ }^{3}$ Embrapa \\ Mandioca e Fruticultura; Rua Embrapa; Cruz das Almas - BA - Brasil. ${ }^{4}$ Faculdade Maria Milza; Cruz das Almas - \\ BA - Brasil
}

\begin{abstract}
The aim of this study was to evaluate the selected 41 SSR markers developed for yellow passion fruit (Passiflora edulis $f$. flavicarpa Sims.) for their transferability to 11 different Passiflora species. Twenty-one SSR were successfully amplified in 10 wild species of passion fruit producing 101 bands. All the markers were amplifiable for at least one species. The mean transferability was 68,8\%, ranging from 15,4\% (primer PE11) to $100 \%$ (PE13, PE18, PE37, PE41 and PE88). Transferability was higher for the species from the Passiflora subgenus than for those from the Decaloba and Dysosmia subgenus. The results indicated a high level of nucleotide sequence conservation of the primer regions in the species evaluated, and consequently, they could potentially be used for the establishment of molecular strategies for use in passion fruit breeding and genetics.
\end{abstract}

Key words: Transferability, SSR, passion fruit

\section{INTRODUCTION}

According to Vanderplank (1996), the passion fruit belongs to the Passifloraceae family, which comprises 18 genera and approximately 630 species distributed in the tropical regions of America, Asia and Africa. The genus Passiflora, whose centre of origin is South America and centre of geographic distribution is the northern and central regions of Brazil, has the largest number of species in the family at approximately 400 (Vitta and Bernacci 2004). However, only approximately 60 species produce fruits with commercial value (Schultz 1968; Manica 1997), either for consumption or medicinal use. Approximately $90 \%$ of the species originated in the Americas (Lopes 1991) and more than 120 of them are native to Brazil (Cervi 1997; Souza and Lorenzi 2005).

Due to its economic and social importance, many studies have been undertaken to develop the varieties that are adapted to different cropping systems and climate conditions. Hence, activities related to the collection, conservation, characterisation and usage of Passiflora germplasm have been implemented to ensure that genetic variability is exploited in breeding programs. Due to its variability, wild species of Passiflora can contribute to the improvement of cultivated passion fruit in many different ways. In Brazil, a number of interspecific hybrids have been developed with the aims of (i) improving the

*Author for correspondence: eder.oliveira@embrapa.br 
agronomic traits, such as resistance to pathogens and cold tolerance; (ii) improving the physical, chemical and taste characteristics of the fruits for the fresh market, or the pulp for sweets, or ice cream; (iii) introducing characteristics, such as self-compatibility, because commercial species are self-incompatible; (iv) reducing the distance between the male and female flower structures to improve insect pollination; (v) contributing to daylength insensitivity; and (vi) developing ornamental hybrids (FAO 2009).

However, genetic variability can only be used efficiently if properly assessed and quantified. Thus, the germplasm must be characterised according to several morphological traits (Crochemore et al. 2003; Plotze et al. 2005; Bellon et al. 2009; Viana et al. 2010), agronomic behaviour (Cerqueira-Silva et al. 2008; Abreu et al. 2009) and molecular diversity (Cerqueira-Silva et al. 2009; Cerqueira-Silva et al. 2010; Viana et al. 2010), enabling advances in the description of genetic divergence among accessions.

Molecular markers have been used in plant breeding and in activities related to the conservation of genetic resources. SSR markers have been developed in P. pohlii (Pádua 2004), yellow passion fruit $-P$. edulis f. flavicarpa (Oliveira 2006), sweet passion fruit $-P$. alata (Pádua et al. 2005), P. ovalis (Kriedt 2009) and $P$. cincinnata (Cerqueira-Silva et al. 2012). This type of marker is highly polymorphic, co-dominant in nature, easy to score by the PCR and abundant in most organisms studied (Oliveira et al. 2006). However, the development of microsatellite markers is time consuming and a high cost activity (Gimenes et al. 2007). This limits the widespread use of microsatellite markers in this genus. A good alternative would be the use of a set of primers to obtain cross-species transferability.

In the transferability, or cross-amplification procedure, PCR primers developed for a studied (source) species are used to amplify microsatellites from closely (Isagi and Suhandono 1997; Harr et al. 1998; Cipriani et al. 1999) or sometimes quite distantly related species (White and Powell 1997; Roa et al. 2000; Zucchi et al. 2002; GonzálezMartínez et al. 2004).

The objective of this study was, therefore, to test the ability of 41 passion fruit SSR primer pairs to amplify the PCR products from 10 species of the genus Passiflora. The transferable markers will immediately increase the pool of available SSR markers in wild relatives of passion fruit. These new markers will be useful in genotyping, characterising species relationships, the introgression of desirable alleles from wild germplasm pools and the application of markerassisted breeding in passion fruit.

\section{MATERIALS AND METHODS}

\section{Plant materials}

Leaf samples from 11 Passiflora species including $P$. edulis, which is used as a check to confirm the size of SSR-fragments (Table 1) were harvested from the germplasm bank of Embrapa Cassava and Fruits, located at Cruz das Almas, Bahia, Brazil $\left(12^{\circ} 39^{\prime} 59^{\prime \prime} \mathrm{S} ; 3^{\circ} 06^{\prime} 00^{\prime \prime} \mathrm{W}\right)$. For each species, between three and five different germplasm plants were sampled.

Table 1 - Species evaluated using $P$. edulis microsatellite primers.

\begin{tabular}{|c|c|c|c|}
\hline Species & Subgenus & Accession name & Number of plants \\
\hline P. caerulea $\mathrm{L}$. & Passiflora & BGM016 & 4 \\
\hline P. cincinnata Mast. & Passiflora & BGM322 & 5 \\
\hline P. edulis & Passiflora & BGM325 & 1 \\
\hline P. foetida L. & Dysosmia & BGM153 & 4 \\
\hline P. gibertii N. E. Br. & Passiflora & BGM008 & 5 \\
\hline P. gibertii N. E. Br. & Passiflora & BGM198 & 5 \\
\hline P. ligularis Juss. & Passiflora & BGM160 & 5 \\
\hline P. ligularis Juss. & Passiflora & BGM248 & 5 \\
\hline P. maliformis L. & Passiflora & BGM032 & 4 \\
\hline P. mucronata Lam. & Passiflora & BGM114 & 3 \\
\hline P. rubra $\mathrm{L}$. & Decaloba & BGM117 & 5 \\
\hline P. setacea DC. & Passiflora & BGM241 & 5 \\
\hline P. setacea DC. & Passiflora & Pérola do Cerrado & 5 \\
\hline P. suberosa L. & Decaloba & BGM152 & 5 \\
\hline
\end{tabular}


DNA extraction, PCR amplification and SSR scoring

DNA isolation was conducted using the fresh leaves according to Doyle and Doyle (1990). A set of 41 SSR loci (Oliveira 2006) were evaluated and selected according to the quality of the amplification products. This resulted in 21 SSRs that were used in this work (Table 2). Polymerase chain reaction (PCR) was conducted in a $20 \mu \mathrm{l}$ final volume, containing $10 \mathrm{ng}$ of DNA template, $0.4 \mu \mathrm{M}$ of each primer (reverse and forward) and $1.0 \mathrm{U}$ Taq DNA polymerase (Invitrogen Co., Carlsbad, CA, USA). Annealing temperature, dNTP concentration, $\mathrm{MgCl}_{2}$ and buffer conditions were optimised as shown in Table 3. The PCR products obtained using DNA from wild species were electrophoresed on 4\% agarose 1000 (Invitrogen Co., Carlsbad, CA, USA) gels stained with ethidium bromide, or on $6 \%$ denaturing polyacrylamide gels stained with silver nitrate. The size of the fragments was estimated based on a 50 bp ladder (Biolabs).

\section{SSR analysis}

Polymorphic loci were characterised with regard to the number of alleles per locus (A), as well as expected $\left(\mathrm{H}_{\mathrm{E}}\right)$ and observed $\left(\mathrm{H}_{\mathrm{O}}\right)$ heterozygosities for each locus, and averaged over all loci using the Powermarker software (Liu and Muse 2005). A dendrogram for determining the relationship among the accessions was constructed using the software MEGA 4.0 (Tamura et al. 2007) based on the unweighted pair group mean average (UPGMA) method (Sneath and Sokal 1973) and the shared allele metric.

\section{RESULTS}

\section{Transferability of SSR markers}

Of the 41 passion fruit-specific SSRs assessed, 21 (51\%) amplified characteristic, reproducible and high-quality bands in at least one Passiflora species. The other 20 markers (PE01, PE02, PE04, PE06, PE08, PE10, PE12, PE14, PE16, PE17, PE20, PE21, PE24, PE26, PE28, PE29, PE35, PE42, PE54 and PE60) amplified unspecific products and they were not used in this work. Table 2 shows the sequences of these primers along with the SSR repeat motif and annealing temperature.

Table 2 - SSR markers used in this study: locus code, sequence of primers, repeated motif, class, and size observed in passionfruit Passiflora edulis Sims f. flavicarpa Deg (Oliveira 2006).

\begin{tabular}{|c|c|c|c|c|c|}
\hline Locus name & Forward sequence $\left(5^{\prime}-3^{\prime}\right)$ & Reverse sequence (5' - 3') & Repeated motif & Class & Size (pb) \\
\hline PE03 & gcagcgagggaagaaaaa & tgagacatcgtgcgtgaa & $(\mathrm{GA})_{10}$ & Interrupted & 156 \\
\hline PE07 & tgctcattgatggtgcttg & tcgtctcttctcetcettca & $(\mathrm{GA})_{23}$ & Interrupted & 138 \\
\hline PE09 & ggaaatccgaaaactggttg & gggcctttatccatgtttga & $(\mathrm{AT}) 5(\mathrm{AC})_{8}$ & Compound & 268 \\
\hline PE11 & gcataagttgtcggtcttgg & cctcgaacctctatcatcca & $(\mathrm{GT})_{11}$ & Perfect & 178 \\
\hline PE13 & aagcaccccaatcgttga & ccccetgccacctgagta & $(\mathrm{GT})_{6}$ & Interrupted & 172 \\
\hline PE15 & accgttaaatccaagcaagt & aaatgcaaaagaatgatatgtta & $(\text { CTTTAGC })_{5}$ & Imperfect & 204 \\
\hline PE18 & ccgtgaaccaaccatttctc & ttgcagcacaaacaagtcaa & $(\mathrm{TG})_{9}$ & Perfect & 220 \\
\hline PE19 & ttaacaggacttagcacttga & ctcatccttcttccatctttg & $(\mathrm{CA})_{14}$ & Perfect & 245 \\
\hline PE23 & caatccettgacccataga & cgtccatccttctcettt & $(\mathrm{GA})_{19}$ & Perfect & 206 \\
\hline PE27 & ttgctcattgcactcatcct & gcagacatttcctggagca & $(\mathrm{GT})_{7}$ & Perfect & 139 \\
\hline PE37 & caaaaggataggcctgatgtc & tgcttggtcatccactgaag & $(\mathrm{TG})_{8}$ & Perfect & 232 \\
\hline PE38 & gatcggtcctcggttagac & agtcacacagcatgagaaatc & $(\mathrm{TG})_{8}$ & Perfect & 215 \\
\hline PE41 & atcggggttcgcttatttg & cgttcatcctttagtgggeta & $(\text { TTAA })_{5}$ & Interrupted & 220 \\
\hline PE58 & gcaatttcaccatcttctgct & ccacggtcatggatgttc & $(\mathrm{AC})_{11}$ & Perfect & 243 \\
\hline PE59 & gaacacttcgcatggctaga & ttccgaatcaaaccgtaact & $(\mathrm{ATCTA})_{3}$ & Perfect & 276 \\
\hline PE64 & atcaattacgcacccaaac & ggaacgtcaatcaagtgagga & $(\mathrm{AC})_{8}$ & Perfect & 228 \\
\hline PE66 & ccatagtcccaacaagcatc & gctgtggaccctaactcagtc & $(\mathrm{AC})_{9}$ & Perfect & 165 \\
\hline PE74 & ccctcttatcaatagcgttgg & gcacgagcacgagtatttatt & $(\mathrm{ATCACA})_{5}$ & Interrupted & 215 \\
\hline PE75 & cacaatcggtgggaaagata & gtagttttgggcagtttgc & $(\mathrm{TG})_{17}$ & Perfect & 178 \\
\hline PE88 & cttcagggtcacacacatt & gttcatcctttagtgggct & $(\text { TTAA })_{6}$ & Interrupted & 293 \\
\hline PE90 & tcaggaagattgcatgttagt & ctgggttttgtttatgttgc & $(\mathrm{AGC})_{5}$ & Perfect & 245 \\
\hline
\end{tabular}


Table 3 - Annealing temperature $\left(\mathrm{TA}^{\circ} \mathrm{C}\right)$, dNTP, buffer and $\mathrm{MgCl}_{2}$ concentration used for each primer, as well as characteristics of SSR primers developed for $P$. edulis and cross-amplified in 10 species (14 accessions) of Passiflora species.

\begin{tabular}{|c|c|c|c|c|c|c|c|c|}
\hline Locus & TA $\left({ }^{\circ} \mathrm{C}\right)$ & dNTP (mM) & Buffer & $\mathrm{MgCl}_{2}(\mathrm{mM})$ & Number of alleles & Allele range & Gene diversity & PIC \\
\hline PE03 & 60 & 0,2 & $1 \mathrm{X}$ & 1,5 & 2 & $140-150$ & 0.50 & 0.37 \\
\hline PE07 & 60 & 0,2 & $2 X$ & 1,5 & 11 & $90-140$ & 0.75 & 0.85 \\
\hline PE09 & 56 & 0,2 & $2 X$ & 1,5 & 10 & $205-280$ & 0.75 & 0.71 \\
\hline PE11 & 60 & 0,2 & $2 X$ & 1,5 & 4 & $270-320$ & 0.69 & 0.64 \\
\hline PE13 & 60 & 0,2 & $2 X$ & 1,5 & 2 & $165-175$ & 0.15 & 0.15 \\
\hline PE15 & 60 & 0,35 & $2 X$ & 1,5 & 9 & $160-220$ & 0.58 & 0.77 \\
\hline PE18 & 60 & 0,35 & $2 X$ & 1,5 & 13 & $170-240$ & 0.70 & 0.86 \\
\hline PE19 & 52 & 0,2 & $1 X$ & 2,5 & 7 & $225-270$ & 0.75 & 0.72 \\
\hline PE23 & 56 & 0,35 & $2 X$ & 1,5 & 5 & $130-200$ & 0.77 & 0.73 \\
\hline PE27 & 60 & 0,2 & $1 X$ & 2,5 & 2 & $145-150$ & 0.18 & 0.16 \\
\hline PE37 & 60 & 0,2 & $1 \mathrm{X}$ & 1,5 & 1 & 240 & 0.00 & 0.00 \\
\hline PE38 & 56 & 0,2 & $1 X$ & 2,5 & 5 & $220-280$ & 0.74 & 0.68 \\
\hline PE41 & 60 & 0,2 & $1 X$ & 2,5 & 2 & $220-225$ & 0.43 & 0.28 \\
\hline PE58 & 60 & 0,2 & $1 X$ & 1,5 & 3 & $300-365$ & 0.41 & 0.37 \\
\hline PE59 & 56 & 0,35 & $2 X$ & 1,5 & 6 & $250-280$ & 0.69 & 0.66 \\
\hline PE64 & 56 & 0,2 & $2 X$ & 1,5 & 2 & $150-240$ & 0.39 & 0.31 \\
\hline PE66 & 60 & 0,2 & $1 X$ & 2,5 & 5 & $240-270$ & 0.77 & 0.67 \\
\hline PE74 & 62 & 0,2 & $1 \mathrm{X}$ & 2 & 5 & $180-260$ & 0.75 & 0.69 \\
\hline PE75 & 60 & 0,35 & $2 X$ & 1,5 & 3 & $140-160$ & 0.58 & 0.34 \\
\hline PE88 & 60 & 0,35 & $2 X$ & 1,5 & 2 & $285-290$ & 0.00 & 0.32 \\
\hline PE90 & 60 & 0,2 & $1 \mathrm{X}$ & 2,5 & 7 & $210-280$ & 0.73 & 0.77 \\
\hline
\end{tabular}

Seven primer pairs (PE07, PE13, PE18, PE19, PE37, PE41 and PE88) amplified the PCR products for all of the Passiflora species but not in all plants of the same species. Only primers PE37 and PE41 produced PCR amplicons in all plants. Eleven primers showed more than $70 \%$ transferability in Passiflora accessions. Three markers PE11, PE38 and PE58 showed transferability $<25 \%$. Primers PE11, PE23, PE38, PE59, PE64 and PE90 only amplified sequences in the species that belonged to the subgenus Passiflora but did not amplify the sequences in the subgenera Decaloba, or Dysosmia; thus, these primers presented an interesting marker for taxonomic distinction. Considering only species from the Passiflora subgenus, successful crossamplification was higher than $73 \%$. However, when considering only species from the Decaloba subgenus, the transferability ratio was approximately $54 \%$.

The accession BGM032 (P. maliformis - subgenus Passiflora) exhibited the highest observed transferability (100\%), while BGM117 (P. rubrasubgenus Decaloba) exhibited the smallest transferability $(42.9 \%)$. A remarkable diversity was observed within the accessions because the amplification ratio varied among the plants of the same accession and among accessions. For example, the observed transferabilities of the $P$. ligularis accessions ranged from 0 (plants of BGM160) to $100 \%$ (plants of BGM248) for the primer PE03. The transferability ratio for each accession is presented in Table 4.

\section{SSR variability from the Passiflora species}

Considering the polymorphic primers, the PIC values ranged from 0.15 (PE13) to 0.86 (PE18), with a mean value of 0.60 (Table 3 ). The number of alleles detected per locus varied from 1 to 13 (mean: 6.2), while the number of genotypes per locus ranged from 1 to 16 (mean: 6.1).

The primer pair PE59 amplified products exclusively for the species belonging to the Passiflora subgenus, but the plants of the $P$. ligularis and $P$. setacea subgenera produced no PCR product. Similarly, considering the primer PE23, amplification was observed only for the Passiflora subgenus species, with the exception of $P$. ligularis and $P$. gibertii.

A dendrogram was constructed using the shared allele distance and the UPGMA method (Fig. 1). The species were split into two groups, one comprising the species from the Passiflora subgenus and the other from the species that belonged to the Decaloba and Dysosmia subgenera. 
Table 4 - Transferability observed for a set of 21 primers pairs developed to $P$. edulis in 10 species (14 accessions) of Passiflora species.

\begin{tabular}{|c|c|c|c|c|c|c|c|c|c|c|c|c|c|c|c|c|c|c|c|c|c|c|}
\hline \multirow{2}{*}{ Specie } & \multirow{2}{*}{ Accession } & \multicolumn{21}{|c|}{ Primers - code PE } \\
\hline & & 03 & 07 & 09 & 11 & 13 & 15 & 18 & 19 & 23 & 27 & 37 & & 41 & 58 & 59 & 64 & 66 & 74 & 75 & 889 & \\
\hline P. ligularis Juss. & BGM160 & - & + & + & - & + & + & + & + & - & - & + & - & + & - & - & - & + & - & + & + & + \\
\hline P. ligularis Juss. & BGM248 & + & + & + & - & + & + & + & + & - & - & + & - & + & + & - & + & + & - & + & + & + \\
\hline P. foetida $\mathrm{L}$. & BGM153 & - & + & + & - & + & + & + & + & - & + & + & - & + & - & - & - & + & + & + & + & - \\
\hline P. rubra L. & BGM117 & - & + & + & - & + & - & + & + & - & - & + & - & + & - & - & - & + & - & - & + & - \\
\hline P. setacea $\mathrm{DC}$. & BGM241 & - & + & + & - & + & + & + & + & + & + & + & 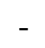 & + & 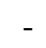 & - & + & + & + & - & + & + \\
\hline tacea $\mathrm{DC}$. & $\begin{array}{c}\text { Pérola do } \\
\text { Cerrado }\end{array}$ & - & + & + & + & + & + & + & + & + & + & + & + & + & - & - & + & + & + & - & & + \\
\hline P. suberosa L. & BGM152 & + & + & + & - & + & - & + & + & - & - & + & - & + & + & - & - & - & + & + & + & - \\
\hline P. cincinnata Mast. & BGM322 & - & + & + & - & + & + & + & + & + & + & + & - & + & - & + & - & + & - & + & + & + \\
\hline P. maliformis L. & BGM032 & + & + & + & + & + & + & + & + & + & + & + & + & + & + & + & + & + & + & + & + & + \\
\hline P. caerulea $\mathrm{L}$. & BGM016 & - & + & + & - & + & + & + & + & + & + & + & - & + & - & + & + & + & - & + & + & + \\
\hline P. gibertii N. E. Br. & BGM008 & - & + & + & - & + & + & + & - & - & - & + & - & + & - & + & + & + & - & - & & + \\
\hline P. gibertii N. E. Br. & BGM198 & + & - & + & - & + & + & + & + & - & - & + & - & + & - & + & + & + & + & + & & + \\
\hline P. mucronata Lam. & BGM114 & - & + & - & - & + & + & + & + & + & + & + & - & + & - & + & + & + & + & + & & + \\
\hline
\end{tabular}

+ denotes high quality amplification; - denotes low quality or no amplification

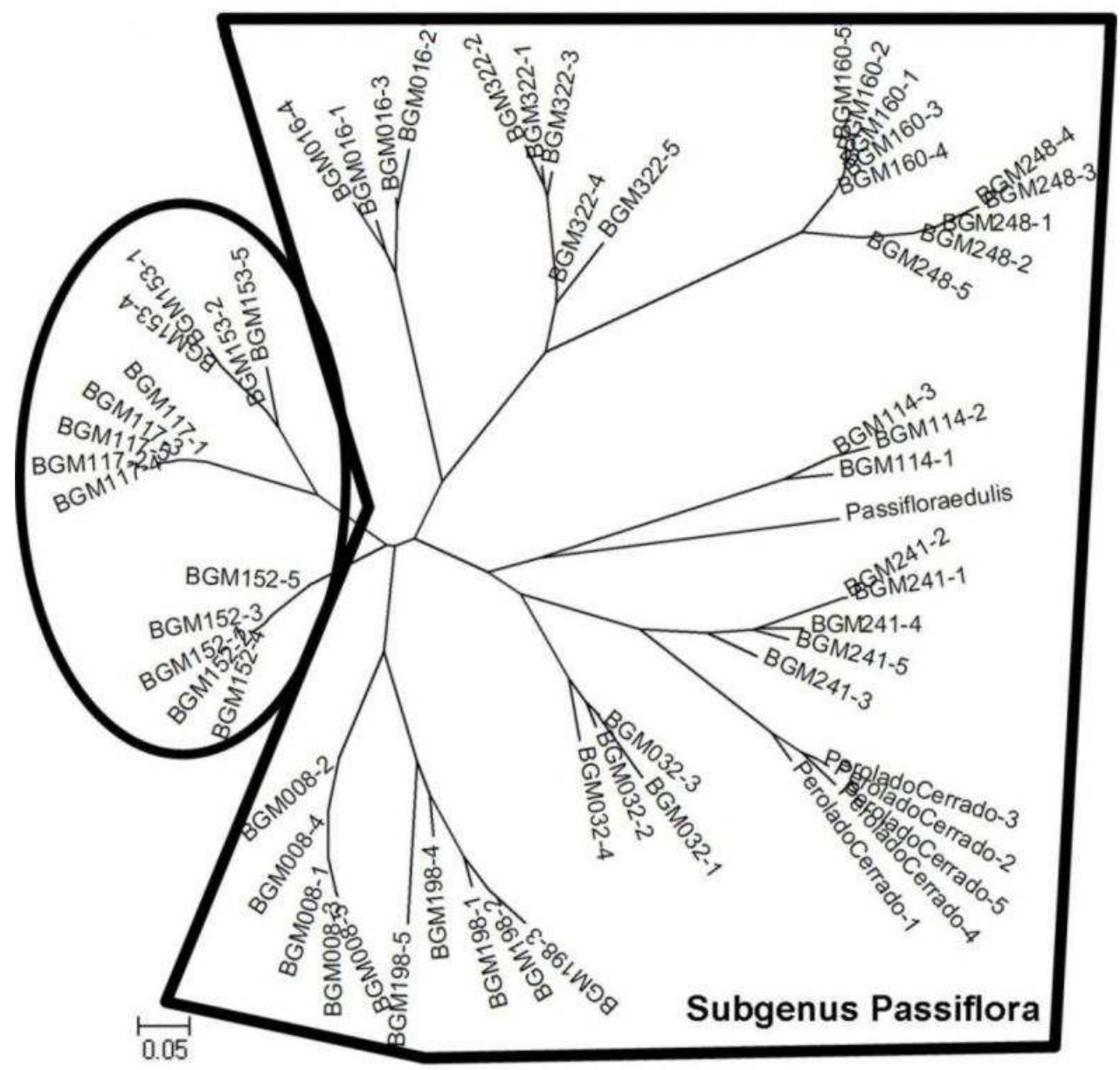

Figure 1 - Clustering of Passiflora genotypes derived from a unweighted pair group mean average (UPGMA) cluster analysis using the Shared allele coefficient based on passionfruit SSR primers. 
In the Passiflora subgenus group, the accessions were clustered according to the species to which they belonged because there were subgroups comprising exclusively by the accessions of $P$. gibertii, $P$. cincinnata, $P$. ligularis, $P$. setacea, $P$. mucronata and $P$. caerulea. For $P$. gibertii, $P$. setacea and $P$. ligularis, in which more than one accession was analysed, all the plants of the same accession grouped together but constituted different subgroups related to the accession to which they belonged. In the non-Passiflorasubgenus group, the accessions were distributed into the homogeneous groups according to their species.

For all the accessions of the species that did not belong to the Passiflora subgenus, a considerable number of primers (PE59, PE23, PE64, PE90, PE38, PE11 and PE03) did not amplify any product.

\section{DISCUSSION}

This study provided an important first step in the development of a set of microsatellite markers suitable for multispecies studies of Passiflora. The primers were tested across a reasonable range of conditions for each species (e.g., varying $\mathrm{MgCl}_{2}$ and dNTP concentrations and annealing temperatures), and results, therefore, provided the information required for more extensive investigations of polymorphisms. The high crossspecies transferability and levels of polymorphisms of microsatellite loci indicated that the application of these markers was a worthwhile and cost-effective approach. Although transferability was in general very high, the number of polymorphic SSRs that amplified the high-quality products was lower, at approximately $53 \%$. This result was in agreement with Barbará et al. (2007), who reviewed 64 primer, representing 611 cross-species. These authors found that in the plants, the transferability of polymorphic markers exhibited a success rate close to $60 \%$ in eudicots.

Generally, the transferability of SSRs isolated from the cultivated species to the wild species decreases as the phylogenetic relationship of the wild species decreases. The results obtained for the genera Manihot (Roa et al. 2000), Arachis (Koppolu et al. 2010), Allium (Lee et al. 2011) and Citrus (Luro et al. 2008) were in agreement with the previously established phylogenetic relationships. In this study, even when considering the species belonging to different phylogenetic clades, good transferability was obtained because all the species could be amplified by a minimum of $49 \%$ of the primer pairs tested.

The transferability ratio was higher in the species that belonged to the subgenus Passiflora than for that of the Decaloba, or Dysosmia subgenera. While the transferability ratio for the subgenus Passiflora was 0.73 , for species that did not belong to this subgenus, the index was 0.54 . Because the source of the markers used in this study was $P$. edulis, a species that belonged to the subgenus Passiflora, this result was clearly explained by the genetic relationship among the species employed.

It was possible to detect the variability within the accessions that was related to allelic size, or to non-amplification. Similarly, the set of transferable markers was able to distinguish the accessions because all the plants for the same accession were clustered together.

The species were split into two major groups. The large group was composed of the species that belonged to the subgenus Passiflora, while the small group comprised the species from the subgenera Decaloba (P. suberosa and P. rubra) and Dysosmia ( $P$. foetida). However, the genetic distance between $P$. rubra and $P$. foetida was lower than that between $P$. rubra and $P$. suberosa, the two species of the Decaloba subgenus.

In addition, possibly due to a high mutation rate in the SSRs (Oliveira et al. 2006), these markers were capable of distinguishing the organisms at the species level but not at higher hierarchical taxonomic levels, such as the subgenus.

However, because the aim of this study was to detect the markers developed for $P$. edulis that could be used to reveal diversity, assist in the breeding programs, mainly for hybrid detection, construct genetic maps based on interspecific crosses, exploit the diversity of the primary gene pool, or assist in recurrent selection proceedings, the inability of these markers to distinguish among the subgenera did not constitute a problem.

The possibility of transferring this set of SSR markers that exhibited very high-quality products would provide an efficient and cost-effective platform for the establishment of molecular strategies for use in the passion fruit breeding and genetics. 


\section{ACKNOWLEDGEMENTS}

The authors would like to thank CNPq, Fapesb and CAPES for fellowships and financial support.

\section{REFERENCES}

Abreu S, Peixoto J, Junqueira N, Sousa M. Agronomic features of six genotypes of passion fruit cultivated in Distrito Federal, Brazil. Rev Bras Frutic. 2009; 31: 920-924.

Barbará T, Palma-Silva C, Paggi GM, Bered F, Fay MF, Lexer C. Cross species transfer of nuclear microsatellite markers: potential and limitations. Mol Ecol. 2007; 16: 3759-3767.

Bellon G, Faleiro F, Peixoto J, Junqueira P, Junqueira N, Fonseca K, et al. Genetic diversity obtained from cultivated population and native accesses of seewt passion fruit based on RAPD markers. Rev Bras Frutic. 2009; 31: 197-202.

Cerqueira-Silva CBM, Santos ESL, Souza AM, Mori GM, Oliveira EJ, Correa RX, Souza AP. Development and characterization of microsatellite markers for the wild South American Passiflora cincinnata (Passifloraceae). Am J Bot. 2012; 99: 170-172.

Cerqueira-Silva C, Cardoso-Silva C, Conceição L, Nonato J, Oliveira A, Corrêa R. Comparison of coefficients and distance measurements in passion fruit plants based on molecular markers and physicochemical descriptors. Genet $\mathrm{Mol}$ Res. 2009; 8: 870-879.

Cerqueira-Silva CB, Cardoso-Silva CB, Santos ES, Conceição LD, Pereira AS, Oliveira AC, et al. Genetic diversity in wild species of passion fruit (Passiflora trintae) based on molecular markers. Genet Mol Res. 2010; 9: 2123-2130.

Cerqueira-Silva CB, Moreira CN, Figueira AR, Correa RX, Oliveira AC. Detection of a resistance gradient to Passion fruit woodiness virus and selection of 'yellow' passion fruit plants under field conditions. Genet Mol Res. 2008; 7: 1209-1216.

Cervi AC. Passifloraceæ do Brasil. Estudo do gênero Passiflora L., subgênero Passiflora. Fontqueria, 1997; 45: 1-92.

Cipriani G, Lot G, Huang W-G, Marrazo M, Peterlunger E, Testolin R. AC/GT and AG/CT microsatellite repeats in peach [Prunus persica (L.) Batsch]: isolation, characterisation and cross-species amplification in Prunus. Theor Appl Genet. 1999; 99: 65 - 72.

Crochemore M, Molinari H, Stenzel N. Agromorphological characterization of passion fruit (Passiflora spp.) germoplasm. Rev Bras Frutic. 2003; 25: 5-10.

Doyle JJ, Doyle JL. Isolation of plant DNA from fresh tissue. Focus, 1990; 12: 13-15.

FAO. The state of use, in: FAO (Ed.), Draft Second report on the World's Plant Genetic Resources For Food and Agriculture, FAO, Rome; 2009. p. 91-115.

Gimenes M, Hoshino A, Barbosa A, Palmieri D, Lopes C. Characterization and transferability of microsatellite markers of the cultivated peanut (Arachis hypogaea). BMC Plant Biol. 2007; 7: 9.

González-Martínez S, Robledo-Arnuncio J, Collada C, Díaz A, Williams C, Alía R, et al. Cross-amplification and sequence variation of microsatellite loci in Eurasian hard pines. Theor Appl Genet. 2004; 109:103-111.

Harr B, Zangerl B, Brem G, Schlötterer C. Conservation of locus-specific microsatellite variability across species: a comparison of two Drosophila sibling species, D. melanogaster and D. simulans. Mol Biol Evol. 1998; 15:176-184.

Isagi Y, Suhandono S. PCR primers amplifying microsatellite loci of Quercus myrsinifolia Blume and their conservation between oak species. Mol Ecol. 1997; 6:897-899.

Koppolu R, Upadhyaya H, Dwivedi S, Hoisington $\mathrm{D}$, Varshney R. Genetic relationships among seven sections of genus Arachis studied by using SSR markers. BMC Plant Biol. 2010; 10:15.

Kriedt RA. Isolamento de marcadores microssatélites para Petunia integrifolia subesp. depauperata (Solanaceae) e Passiflora ovalis (Passifloraceae), Universidade Federal do Rio Grande do Sul. Instituto de Biociências. Curso de Ciências Biológicas: Ênfase Molecular, Celular e Funcional: Bacharelado; 2009.

Lee G-A, Kwon S-J, Park Y-J, Lee M-C, Kim H$\mathrm{H}$, Lee J-S, et al. Cross-amplification of SSR markers developed from Allium sativum to other Allium species. Sci Hortic. 2011; 128: 401-407.

Liu K, Muse SV. PowerMarker: an integrated analysis environment for genetic marker analysis. Bioinformatics, 2005; 21: 2128.

Lopes SC. Citogenética do Maracujá, Passiflora spp, in: São José AR (Ed.), A cultura do maracujá no Brasil, FUNEP; 1991. p. 201-209. 
Luro F, Costantino G, Terol J, Argout X, Allario T, Wincker P, et al. Transferability of the ESTSSRs developed on Nules clementine (Citrus clementina Hort ex Tan) to other Citrus species and their effectiveness for genetic mapping. BMC Genomics. 2008; 9:287.

Manica I. Maracujá: Taxonomia - anatomia morfologia, in: São José BC, Manica I, Hofmann M (Ed.), Maracujá: Temas selecionados Melhoramento, morte prematura, polinização, taxonomia Cinco Continentes, Porto Alegre; 1997. p. 7-24.

Oliveira EJ. Desenvolvimento e uso de marcadores microssatélites para construção e integração de mapas genéticos de maracujá-amarelo (Passiflora edulis Sims f. flavicarpa Deg.) [PhD Thesis]. Piracicaba: Escola Superior de Agricultura "Luiz de Queiroz"; 2006.

Oliveira EJ, Pádua JG, Zucchi MI, Vencovsky R, Vieira MLC. Origin, evolution and genome distribution of microsatellites. Genet Mol Biol. 2006; 29: 294-307.

Pádua JG. Análises genéticas de espécies do gênero Passiflora L. com base em abordagens filogenéticas, morfométricas e em marcadores microssatélites [PhD Thesis]. Piracicaba: Escola Superior de Agricultura "Luiz de Queiroz"; 2004.

Pádua JG, Oliveira EJ, Zucchi MI, Oliveira GCX, Camargo LEA, Vieira MLC. Isolation and characterization of microsatellite markers from the sweet passion fruit (Passiflora alata Curtis: Passifloraceae). Mol Ecol Notes. 2005; 5: 863865.

Plotze R, Falvo M, Pádua J, Bernacci L, Vieira M, Oliveira $\mathrm{G}$, et al. Leaf shape analysis using the multiscale Minkowski fractal dimension, a new morphometric method: a study with Passiflora (Passifloraceae). Am J Bot. 2005; 83: 287-301.

Roa AC, Chavarriaga-Aguirre P, Duque MC, Maya MM, Bonierbale MW, Iglesias C, et al. Cross-species amplification of cassava (Manihot esculenta) (Euphorbiaceae) microsatellites: allelic polymorphism and degree of relationship. Am J Bot. 2000; 87: 1647.
Schultz A. Introdução ao estudo da botânica sistemática Globo, Porto Alegre; 1968.

Sneath PHA, Sokal RR. Numerical taxonomy. The principles and practice of numerical classification; 1973.

Souza VC, Lorenzi H. Botânica sistemática - Guia ilustrado para identificação das famílias de fanerógamas nativas e exóticas no Brasil, baseado em APG II Instituto Plantarum, Nova Odessa (SP), Brazil; 2005.

Tamura K, Dudley J, Nei M, Kumar S. MEGA4: molecular evolutionary genetics analysis (MEGA) software version 4.0. Mol Biol Evol. 2007; 24:1596-1599.

Vanderplank J. Passion flowers. 2nd ed. MIT Press, Cambridge, Mass; 1996.

Viana A, Souza M, Araújo I, Corrêa R, Ahnert D. Genetic diversity in Passiflora species determined by morphological and molecular characteristics. Biol Plant. 2010; 54:535-538.

Vitta F.A, Bernacci LC. A new species and two overlooked species of Passiflora (Passifloraceae) from Brazil. Brittonia. 2004; 56:89-95.

White G, Powell W. Isolation and characterization of microsatellite loci in Swietenia humilis (Meliaceae): an endangered tropical hardwood species. Mol Ecol. 1997; 6:851-860.

Zucchi M, Brondani R, Pinheiro J, Brondani C, Vencovsky R. Transferability of microsatellite markers from Eucalyptus spp. to Eugenia dysenterica (Myrtaceae family). Mol Ecol Notes. 2002; 2:512-513. 